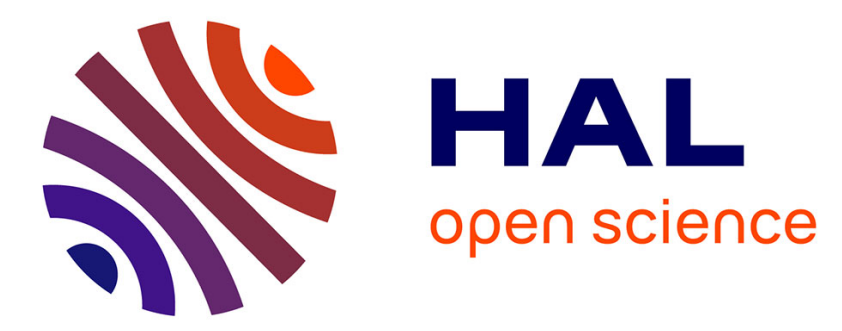

\title{
The reorganisation of drinking water quality governance in France. Responsibility-based governance and objective-driven policy setting in question
}

\author{
Aurélie Roussary
}

\section{- To cite this version:}

Aurélie Roussary. The reorganisation of drinking water quality governance in France. Responsibilitybased governance and objective-driven policy setting in question. Revue d'Etudes en Agriculture et Environnement - Review of agricultural and environmental studies, 2014, 95 (2), p. 203 - p. 226. 10.4074/S196696071401203x . hal-00996875

\section{HAL Id: hal-00996875 https://hal.science/hal-00996875}

Submitted on 27 May 2014

HAL is a multi-disciplinary open access archive for the deposit and dissemination of scientific research documents, whether they are published or not. The documents may come from teaching and research institutions in France or abroad, or from public or private research centers.
L'archive ouverte pluridisciplinaire HAL, est destinée au dépôt et à la diffusion de documents scientifiques de niveau recherche, publiés ou non, émanant des établissements d'enseignement et de recherche français ou étrangers, des laboratoires publics ou privés. 


\title{
The reorganisation of drinking water quality governance in France. Responsibility-based governance and objective-driven policy setting in question
}

\author{
Aurélie ROUSSARY* \\ * Irstea, UR ADBX, F-33612 Cestas et Université Toulouse le Mirail, CNRS, UMR5044 \\ CERTOP, F-31058 Toulouse, France \\ e-mail:aurelie.roussary@irstea.fr
}

\begin{abstract}
The 2000 Water Frame Directive (WFD) has led to changes in the governance of drinking water quality in France. These changes are based on an intensified implementation of mechanisms to create interdependence among stakeholders, making them collectively responsible for fulfilling $E U$ objectives. By observing the implementation of both old and new regulatory devices for drinking water protection, we can gain a good indication of whether or not any tangible changes to territorial management are taking place. From a qualitative point of view, we can see that there is a long history of palliative management of sanitary risks - i.e. treating the symptoms of agricultural pollution rather than the causes. However, new methods of territorial governance are also starting to come to light. This is as a result of the involvement of new bodies in the implementation of agri-environmental devices, such as local authorities and market stakeholders.
\end{abstract}

Keywords: drinking water, agri-environment, public policies, palliative management 


\section{La recomposition de la gouvernance de la qualité de l'eau potable en France. Le gouvernement par la responsabilité et l'exigence de résultat en question}

Résumé - La Directive cadre sur l'eau de 2000 (DCE) a induit des changements dans la gouvernance de la qualité de l'eau potable en France. Ils s'appuient sur une intensification de mécanismes de mise en interdépendance d'acteurs parties prenantes rendus collectivement responsables de l'atteinte d'objectifs sanitaires et environnementaux fixés par l'UE L'analyse a porté sur la mise-en-œuvre de deux dispositifs réglementaires de protection de la ressource en eau potable, un ancien et un nouveau, pour mesurer l'effectivité du changement dans la gestion territoriale de l'eau potable. L'enquête qualitative montre une longue histoire de gestion palliative des risques sanitaires qui privilégie le traitement des symptômes des pollutions d'origine agricole à celui des causes. Des nouvelles formes de gouvernance territoriale commencent aussi à émerger. Elles sont le résultat de l'intervention de nouveaux entrants dans la mise-en-œuvre des dispositifs agri-environnementaux, tels que les collectivités locales ou les acteurs du marché.

Mots-clés : eau potable, agri-environnement, politiques publiques, gestion palliative

JEL Classification: Z18, Q18, Q25 


\section{Introduction}

This article aims to show what new developments in drinking water management mean to the various stakeholders, and whether or not they will improve the governance of drinking water quality in France.

In France, 40 years of water policy (1964-2006) are often presented as symbolic of a French model of integrated management in water catchment basins. This experience-along with 20 years of European Agri-Environmental policy (Common Agricultural Policy of 1992)—leads to a somewhat paradoxical situation. On the whole, the quality of distributed ${ }^{1}$ drinking water has improved thanks to curative (water treatment) and palliative solutions (interconnection and closure of resources). However, the quality of resources used to produce drinking water continues to deteriorate, mainly due to the impact of agricultural pollution (nitrate fertilisers, pesticides) (Ministry of Health 2008, 2010). The main consequence is that the end users are ultimately paying more for their water (IFEN, 2007). This imbalance is symptomatic of entirely separate water management approaches operating at the same time.

On one side, there is the local authority approach, whose main goal is simply to provide residents with drinking water. This bureaucratic, technical and hygiene-driven approach was particularly prevalent in the years immediately following the World War II, when houses were systematically being connected to the drinking water distribution network. This management method has gained even greater favour over the last few decades, as European drinking water quality standards have become more and more stringent. As an example, in the 1900s, there were five drinking water quality parameters. There are now 59. On the other hand, there is the co-operative set-up, whereby agricultural professionals work together with the State to manage agricultural pollution.

In addition to its presence within Water Agencies ${ }^{2}$ (Narcy, 2004), this "split management" phenomenon can also be found on a spatial level, with a clear division between territories where drinking water was produced,

\footnotetext{
1 The term "drinking water distributed" indicates water supplied by a public or a private distribution network, packaged water, and water used by food companies, with the exception of natural mineral waters and medicinal waters.

2 The six French water agencies are public bodies regulated by the Ministry for Ecology, Energy, Sustained Development and Spatial Planning. These organisations are responsible for the planning of Water policy and the financial incentivisation in seven major river basins. A water agency collects charges for water use based on the "polluter-payer" and "taker-payer" principle, granting financial assistance to fight pollution, improve water resource management, and restore aquatic environments. As part of the national and European water management policy, the water agency implements the guidelines defined by River Basin Committees, which like a kind of "water parliament", bring together the representatives of water stakeholders (local authorities, users, voluntary organisations and the State).
} 
and territories where agri-environmental measures were most often actually implemented. Lastly, this division can also be seen in the theoretical debate between different fields of research (science of engineering, management and economics) and within the human and social sciences.

However, the existence of these two "camps" is now beginning to cause problems and the paradox surrounding them is more obvious than ever. It would be fair to say that the situation has reached crunch point. The continuous increase in the vulnerability of drinking water to agricultural pollution, the need for more sustainable water supplies (quantity and quality), increasing calls for greater transparency, cost sharing and more equal access to drinking water (quality and price) can no longer be ignored. These issues contribute to increased interdependence between health and environmental policies.

In Europe, the cornerstone of this new move towards interdependence is the 2000 Water Framework Directive (WFD) (2000/60/EC). It sets out sanitary, environmental, economic and social performance targets for drinking water services, which-if not achieved-can lead to financial penalties for the French Government. In order to fulfil the EU requirements, there needs to be a combination of the bureaucratic and technicist approach to sanitary risks (anthropocentrist referential) with the newer environmental participative approach (ecocentrist referential).

The model of integrated water management advocated in the French transposition of the WFD is supposed to be applied to the State and French water agencies. Its implementation calls for clarification of the mechanisms of multi-partnership cooperation between two categories of stakeholder at multiple levels of governance. These stakeholders are both public and private parties, involved in both drinking water and agricultural pollution management.

Following the example of other European countries such as the United Kingdom (Faucher-King and Le Galès, 2007) who have already applied the internationally-recognised principle of new public management, France has embarked on a series of political, economic and social reforms, encompassing the Organic Law on Laws of Finance (2001), the latest decentralisation laws (2003-2004), the Charter on the Environment (2004), the General Review of Public Policies (2007), and the Territorial Reform Law (2010). These actions promote subsidiarity, greater rationalisation and individual and collective accountability. Results-orientated assessment has been presented by the French government as a prerequisite for integrating territorial strategies, participative democracy and efficient public policies on health and the environment. As a result of this, French stakeholders now find themselves in a situation where they are both interdependent and collectively responsible for satisfying environmental objectives, for the benefit of the ordinary water consumer. Governance through responsibility and accountability transforms the relationship between stakeholders (Hache, 
2007; Salles, 2009). It does this through the proliferation of monitoring, surveillance and accountability-related devices and tools (Costa et al., 2001). It also introduces user participation, through such methods as participative observatories, public meetings and debates and complaint handling (Notte and Salles, 2011).

This changing situation gives rise to the following questions: How does a result-orientated approach to the management of drinking water and the imposition of accountability through compulsory targets affect regulatory drinking water protection devices? In what way do these new measures reshape the organisation of the public authorities responsible for implementing them?

We predominantly used a bottom-up method to analyse the dynamics of collective action at a territorial level. Studying information at this level is the only way to see the combined functioning of public policy, local governance and the social, political and geographical context. It is also an effective way of observing the reorganisation of drinking water quality governance.

More than ever before, we can see a use of public policy instrumentation (Lascoumes and Le Galès, 2004) in relationships between the government and the public. In this approach, governmental devices directly manage the actions of stakeholders and other organisations to be managed through the use of devices. These public action tools have more or less standardised technical, procedural and regulatory characteristics. They are a vehicle for different political decisions, as well as representing problems and their underlying issues. It can therefore be said that these tools partly determine collective action (mobilisation of stakeholders and distribution of resources) as well as opening up the possibility of differentiated appropriation. On this basis, it is clear that these devices can be a very effective way of tracking the reorganisation of public action in drinking water protection. There are complex vertical and horizontal dynamics attached to multilevel governance of drinking water quality and contemporary public action (i.e. Europeanisation, "territorialisation", market dynamics, institutional reform and consultation with end users). We mainly interpreted them through their actual impact on organisational processes and how legislative devices for drinking water protection are implemented. From this point of view, we observed reorganisation within a basin, region, département (French regional unit) ${ }^{3}$, or on a local basis.

In order to fully understand the complex and varied topic of drinking water governance, it was necessary to examine a large number of documents. However, the main data for this paper comes from 52 semi-directive interviews carried out between 2004 and 2009. These interviews involved

3 A Département is a French territorial area, and an administrative unit based on specifications dating back to the 1789 Revolution (96 in the metropol and 4 overseas). Départements are administered by two different bodies: a deliberating body (assemblée départementale) and an executive body (the President of the General Council). 
different stakeholders in the field of drinking water management in Southwest France: politicians, administration staff, professionals, ecologists and representatives from different associations. Over a period of 18 months, we also attended meetings with a working group from the decentralised services of the French Health Ministry in the Midi-Pyrénées Region. On top of this, we collated both formal and informal documents, from a variety of sources, both inside and outside French water institutions.

The first part of this paper covers water protection regulations that have been in force since 1964, but are not applied with any form of consistency. Our analysis shows the predominance of a palliative approach to sanitary risk management. This approach targets the symptoms of water pollution from agricultural chemicals, but does not take into account the causes. As a result of this, the vulnerability of water to environmental risks-and therefore that of the end user-is increased. In the second section, we will examine a new, emerging legislative device, which was designed to satisfy the results-orientated requirements of the WFD. We will see that the introduction of integrated management of drinking water services is by no means a foregone conclusion. In addition to this, it is clear new forms of territorial drinking water governance are beginning to appear. These changes are being brought about by the arrival of new stakeholders on the drinking water scene, such as local authorities and private companies with an interest in the farming sector. All of these new factors, along with a method of drinking water governance that is still suffering from the effects of corporatism, mean that administrators need new types of abstract tools.

\section{Dominance of a symptom-based approach to sanitary risk management for drinking water supplies}

\subsection{Forty years of regulations failing to protect drinking water catchments}

Local authorities are responsible for ensuring the supply of safe drinking water to the public, and making sure that the perimeters of drinking water catchments are properly enforced, in keeping with legal requirements (Box 1).

\section{Box 1. Drinking water quality legislation}

In Europe, drinking water is principally governed by directives 75/440/EEC (16 June 1975), concerning the quality of surface water intended for the abstraction of drinking water, and directive 98/83/EC (3 November 1998) on the quality of water intended for human consumption. The latter is a revised edition of a previous directive (80/778/EC: 1980), which was integrated into French law by decree number 2001-1220 (20 
December 2001) and added into the French health code in 2003 (articles R132-1 to R132-66).

This legislation imposes five different types of administrative and technical regulations relating to the supply of water for human consumption:

- Protective and preventative rules to ensure the smooth running of water networks from the catchment area right through to supply.

- Administrative procedures involving hydrogeologists and other specialist consultants at both national level, through the French Agency for Food, Environmental and Occupational Health \& Safety (ANSES), and local level, through CODERST (departmental committee on technological risks, health hazards and environmental issues).

- Quality standards for 59 different parameters relating to drinking water as well as quality control for bodies of water.

- Continuous monitoring by managers at local level, along with "command and control" by the health authorities in monitoring the quality of water supplied to consumers.

- Requirements for the exchange of information between local officials and the authorities, as well as freedom of information for water users in case of any sanitary issues. Periodical reports must also be submitted to the European Commission.

These regulations aim to prevent "any cause of local, isolated or accidental pollution that may affect the quality of water obtained from that area". The protection of water catchments first appeared in the French public health act in 1902, and was made compulsory in 1964. All water treatment plants require an operating licence from the Préfet ${ }^{4}$ (the senior government representative in a Département). This licence is only granted once the vulnerability of a particular catchment has been assessed. In addition to this, as a preventative measure, three perimeters must be installed: one immediately surrounding the catchment, a second on the approach and a third in the wider surrounding area ${ }^{5}$. The first step in the implementation of these measures is for the Préfet to sign a "declaration of public utility", which is then added to the "local urban plan" document. This declaration contains all the measures to be put in place by the relevant local authority: fencing off of the immediate area, work to be carried out, particular obligations to be applied to certain local activities and any associated compensation payments to be made.

Legally speaking, in the event of any incident resulting from insufficient protection of these catchments, the blame would fall collectively on drinking

\footnotetext{
4 The Préfet is appointed by presidential decree.

5 The provisions of only the first two perimeters are compulsory, the wider one being at the discretion of the local authority.
} 
water suppliers, the State, and the relevant local authority, since these bodies are collectively responsible for that protection. While local authorities are nominally responsible for putting perimeters in place, the Préfet can legally "go over their head" and carry out the work directly in case of any serious shortcomings. Also, the process of implementing protective perimeters is handled by a number of other decentralised government bodies (regional health agency and departmental directorate of territories). At national level, these authorities can be called to account in one of two ways. Either the measures set out by the Préfet are unsuitable for risks present in the area in question, or those measures are not correctly applied by the relevant local authority. As far as Europe is concerned, whatever body is responsible for a given oversight, the responsibility rests with central government in the member state.

Despite the fact that these measures have been compulsory for over forty years and despite the potential consequences, they are still not consistently applied, although their implementation has been stepped up over the last few years. However, in 2006, just 48 percent of drinking water catchments were properly designated, representing a formally protected water supply for 56 percent of the population (IFEN, 2007). The effectiveness of such protection is thus questionable (Barbier, 2011).

If we apply a strictly legalistic approach, excluding all political considerations, then the rules ought to be applied to the letter of the law, and in a standardised fashion. However, this study shows that in practice-over a forty-year period-procedures have been adapted to suit the requirements of different institutions, resulting in another set of "unofficial" rules by which the protection of catchments is implemented. This "understanding" between the French administration, scientific experts, local government and agricultural representatives has created a more or less stable modus vivendi. It also presents various possibilities for "pragmatic adaptation" (Lascoumes, 1990) and "strategic appropriation" (Busca, 2010) of the regulations by stakeholders. This pragmatic approach means that the rules are not systematically applied throughout France. In most areas, progress is extremely slow, whereas in a small minority of zones, it exceeds the laid-down requirements, with cooperative agreements being drawn up between local authorities and farmers (Salles et al., 2006; Barraqué et al., 2007).

One problem is that the notion of protective perimeters first appeared at a time when agricultural non-point pollution was not particularly well known. Regulations in force did not distinguish between point and non-point source pollution. Because of this, each stakeholder involved in the creation of these perimeters applied their own standards as to their effectiveness, the way in which they were to be used, the size of the area to be protected, and the extent to which farming needed to be restricted. These choices were influenced by hydro-geological and socioeconomic considerations, the severity of health risks, state of the water source in question and inter-institutional relations. It was not until the first "National Health and Environment Plan" (2004) that 
protective perimeters were officially recognised as being primarily suited to point source pollution. This text also specified that non-point source pollution was to be dealt with by an alternative method. However, this new instrument did not appear until the end of the 2000s.

Overall, we can see that due to a lack of other tools to protect drinking water resources against non-point source pollution, public authorities were stuck with a choice between three solutions that were not necessarily mutually exclusive: an expensive commitment to long and uncertain negotiations with farmers, the implementation of a bare minimum of measures (e.g. warnings relating to farm compliance), or exit-i.e. the abandonment of water catchments (Hirschman, 1970) ${ }^{6}$. Indeed, we can see that the recent lack of effectiveness is less due to technical and bureaucratic difficulties, and more to do with factors relating to local policy, and the unwillingness of local decision makers to place restrictions on intensive farming. Catchment perimeters impose constraints on intensive agriculture, such as bans on crop planting. Many local authorities are simply not prepared to risk the social and political disputes that would inevitably result from taking such action. One of the reasons that the system has not been more widely implemented is the disproportionate nature of the issues involved. Reducing health risks is in everyone's interest. However, political, economic and social issues only affect the stakeholders located within the local area (local authorities and farmers), despite the fact that pollution is not always produced locally. This explains why preventative measures are still relatively rare.

Regulations may be enforced more stringently in peri-urban areas-as part of an "interventionist" approach to local government-than in predominantly rural areas, where the authorities generally try to avoid interfering with local activities in order to "keep the peace" (Salles et al., 2006). This approach is also widespread among departmental authorities (Préfet, General Council), and serves to undermine the importance of protective perimeters. In practical terms, the threat of sanctions carries less weight, as those receiving the warnings are well aware that the authorities wish to avoid penalising local farmers.

As a result of this reluctance to upset the status quo, water managers in high-pressure agricultural areas tend to focus on treating pollution rather than removing the causes. This is reflected in the amounts of public money

6 The "secondary standards of application" of procedural frame (Lascoumes, 1990) and the mechanisms of territorial strategic appropriation (Busca, 2010) are applied at various levels of procedural effectiveness (administrative and material) and at various levels of responsibility. They are applied to for procedural frameworks through "norms of interpretation" (circulars, internal administrative guide, assistance of the General Councils), to institutions through "norms of negotiation" (conditions of the exercise of expertise, device purpose) and mainly to territories through conflict avoidance strategies. 
allocated to water services ${ }^{7}$. In the short term, this allows them to satisfy cleanliness criteria, but in the long term, the overall quality of drinking water is not being improved. This approach is due to water quality being managed on a sectoral basis, rather than the relevant policy-setting departments (agriculture and public health) working together to resolve problems. As long as drinking water pollution is artificially kept under control in this way, it will never be "risk classified" (Borraz et al., 2005), and thus become a key issue on the (national) political agenda.

Local authorities with greater financial means (urban areas or those responsible for several municipalities) are essentially able to sidestep the process of negotiating with farmers, by seeking out new, less contaminated, sources of water. They may also be able to buy up land within a water catchment perimeter, eventually "sanctuarising" the area (Roussary, 2013). However, it is important to remember that focusing exclusively on "sterile" areas diverts public attention away from more heavily polluted areas.

Local authorities and government representatives have to deal with ever increasing sanitary, agricultural, social and political pressures. This means that more and more manpower, equipment and money are being concentrated on the preservation of officially-designated "strategic" resources on a départemental level. This approach is part of a wider policy of "rationalisation". An example of this is the abandonment of contaminated drinking water catchments, or the use of network interconnection. These measures often appear to local authorities to be the most sensible course of action (from a sanitary, financial and political point of view) in the case of pollution. Empirical research has shown that rationalisation could lead to a real shake-up of the current drinking water management system (Canneva and Pezon, 2008) in France, notably with the introduction of regulation on a départemental level (a larger area) (Grandgirard et al., 2009; Barbier et al., 2011), rather than each local authority or group of local authorities overseeing their water supply individually. That said transferring responsibilities to a higher authority does not automatically result in greater consideration for the environment or greater participation from end users (Roussary, 2013).

In both day-to-day management of drinking water services and in times of emergency (e.g. bans on water consumption due to agricultural pollution) there is a significant leaning towards symptom-based measures (curative and palliative). This method of dealing with these problems is the result of "disengaged public action" for the quality of drinking water (Becerra and Roussary, 2008). It is important to note that territorial interdependence that increasingly relies on strategic resources can have unintended side effects. A symptom-based approach ignores the causes, leaving them to be dealt with

\footnotetext{
7 According to the French Court of Auditors (2010), the amount of curative funding provided by water agencies between 2007 and 2012 was 1.8 times that provided for preventative purposes (e.g. modifying farming practices). The exact figures were 1.29 billion $€$ for the former versus 712 million $€$ for the latter.
} 
by somebody else (e.g. those responsible for agricultural policy). Risks posed to the environment are discounted and trivialised (Becerra and Peltier, 2009). The net result of all these factors is that water networks become more and more interconnected and centralised, therefore apparently technically more "rational". But in the same time water resources become also more vulnerable, which inevitably poses an increased health risk to the general public. Perhaps more importantly for local councillors and public bodies, they run the risk of losing political kudos.

The last two decades have seen a tightening up of European water laws (1998 Drinking Water Directive and 2000 Water Framework Directive). In addition to this, several French water consumers have issued proceedings in the EU court system against their own government, for failure to comply with the legislation. Issues such as these highlight the problems with the current approach to drinking water catchment protection in France. More and more consumer watchdogs are complaining that public health is being put at risk, due to the failure of many catchments to satisfy safety regulations.

French water and public health laws were recently reformed, to bring them into line with EU regulations. As a result of this, stakeholders involved in water catchment protection have become the subject of a greater top-down institutional pressure. These laws called for a 100 percent formal protection rate (perimeters) for water catchments by 2010, which is in line with European water protection specifications.

\subsection{Objective-driven water catchment protection: A path towards real change?}

Through studying the water catchment perimeter device, we can observe the way in which institutional changes take place. In this case, it is clear that an objective-driven approach has very little effect on the device itself. However, the introduction of firm targets leads to a change in the set-up of different institutions and modifies the way that stakeholders interact with each other. A wide range of adaptations took place, aimed at moving from a means-driven approach to one with defined goals. These changes were organised in such a way as not to modify the device itself, or provide any more manpower to decentralised State services. The adaptations in question involved the relaxation of certain administrative requirements, reminding relevant experts and administrative staff to concentrate only on cases of accidental pollution, and a transfer of responsibility between state departments. At the same time, administrative departments and elected representatives began to experience multilevel institutional pressure as a result of more widespread use of continuous monitoring and evaluations. Health authorities became more geared towards carrying out inspections of drinking water services, and fining underperforming areas. 
Given that these targets were first established in 1964, and when we consider that a mere 40 percent of water catchments were protected in 2004, it is questionable whether or not these adaptations were ever going to reach the laid-down objectives of 100 percent protection by 2010. Such deadlines cannot be put in place without first considering the political issues attached to drinking water management. Each catchment area has its own political scene. Since research into "peripheral power" was first carried out (Grémion, 1976; Duran and Thoenig, 1996), we have known that these political implications cannot be ignored by decentralised government services.

From an environmental point of view, water catchment perimeters cannot protect water resources from modern pollution risks on their own. Nevertheless, they are an important part of any standard-setting framework concerned with drinking water protection. These perimeters are the only tool available for local authorities looking to plan water management and clearly define protected zones within their catchment areas.

Partly due to greater coverage of water pollution issues in the media, an increasing number of stakeholders were placed under mounting pressure, and found themselves in a situation of interdependence. They were forced to come up with sometimes hurried solutions to ensure a sustainable supply of water. Paradoxically, a legalistic approach — setting stringent objectives and fining those who fail to comply-is largely ineffective in re-energising drinking water resource protection policy. Quantitative result-driven governance can have several unintended effects. Notably, stakeholders tend to favour short-term (curative and palliative) solutions - a rapid way of gaining political brownie points - over longer-term preventative solutions whose political benefits will take longer to be realised. The way in which stakeholders place their own interpretation on water regulations is indicative of a widespread mistrust of State directives. Given that the French government is required to satisfy a set of EU objectives, water agencies and local authorities could well be used as scapegoats in the event that these goals are not achieved. We can see that the government has already begun trying to transfer responsibility for non-compliance to these stakeholders ${ }^{8}$.

Drinking water catchment policy illustrates the way in which new public management has begun to remodel government policy (Bezes, 2008). Criticism of water services' abilities to police compliance with regulations has been used to justify a shake-up in the organisation of these bodies. For example, poor sanitary and environmental performance can be used as an argument for carrying out increasingly stringent checks. In addition to this,

\footnotetext{
8 The government had considered extending the scope of the current French law (general code of territorial authorities) L.1511-1-1, meaning that all penalties incurred by the State as a result of negligence by a territorial authority would be payable by the authority in question. The French home secretary, referring to this possibility in a government report entitled "Sustainable water management tools" (pp. 650-651), said that there needed to be "additional ministerial dialogue".
} 
the reluctance of many local authorities to implement new regulations means that any financial penalties incurred by the Government could be transferred to them. This, in turn, would mean a hike in the price of water for the end user.

Despite external and internal changes in French institutions, water catchment protection seems to be stuck in an unshakeable situation of path dependence (Pierson, 2000). As long as drinking water supplies are managed in a palliative manner, and changes in farming methods remain confined to agrienvironmental policy (regulatory, incentive and contractual), this is unlikely to change. A great deal of previous research has shown the ineffectiveness of agri-environmental policies on environmental issues, along with the purpose deviation encountered in their implementation (Salles, 2006; Bourblanc, 2007; Daniel and Perraud, 2009; Busca, 2010; Roussary et al., 2013).

The territorialisation of environmental policy means that agrienvironmental devices are placed more and more in areas with "drinking water issues". However, their institutional management (joint management between farmers and State administration) remains separate from the drinking water management system (local authorities, water supply partnerships, drinking water supply syndicates and départements). Article 7 of the WFD specifies: "member States shall ensure the necessary protection for the bodies of water identified with the aim of avoiding deterioration in their quality in order to reduce the level of purification treatment required in the production of drinking water". These two "camps" need to combine to create an integrated system of drinking water management.

In the absence of any other regulatory protection tool, water catchment perimeters have been used since the 1960s as a way of protecting drinking water supplies from both point source and diffuse pollution. However, the varied nature, pertinence and complexity of the issues involved (sanitary, environmental, social and political) show us that the government needs to create new instruments (Lascoumes and Le Galès, 2004). It was not until the end of the 2000s, and following 10 years of results-driven governance, that a specific device to protect drinking water from agricultural diffuse pollution was put in place (French Water Law in 2006; French Environmental Summit in 2007).

\section{Is France moving towards integrated drinking water management and joint territorial responsibility?}

\subsection{The emergence of a hybrid device-500 "priority catchments"}

This section examines the different forms of collective action that are beginning to appear. The methodology and organisation of these new approaches seem to show that lessons have been learnt from previous failures. 
The "water catchment area"9 device is part of a long-standing reform of the 1992 French Water Law, which was finally passed by parliament in 2006. However, this device was only recognised as being of public interest following the 2007 French Environmental Summit ${ }^{10}$, and even then, its importance was restricted to a list of 500 "priority water catchments", out of some 36,000 throughout France. It was presented as the most appropriate way of restoring coherence and efficiency to public drinking water policy. Aside from this "ambitious" objective, the device also presents three innovations conducive to the combined use of classic methods of drinking water supply management and territorialised agri-environmental devices ${ }^{11}$.

The first innovation is a regulatory device aimed specifically at diffuse pollution, falling into the remit of local authorities. The second innovation is the fact that these authorities are responsible for the concerted definition and implementation of agri-environmental incentives and territorialised action plans. The third is the possibility for the Préfet to revise and/or make agri-environmental measures compulsory three years after they are published. In cases where the Préfet considers that objectives are unlikely to be realised, this delay can be reduced to twelve months ${ }^{12}$.

This device creates interdependence between State representatives, local authorities and the water agency of a given territory. In other words, these bodies are collectively responsible - and indeed can be collectively

9 Water catchment areas are defined according to hydro-geological criteria. They can cover several hundreds, sometimes thousands, of hectares. They represent areas where "water entering streams is destined, or will be destined at some point in the future, for public consumption". (Identification of 500 catchments Grenelle, [on-line], http://www.ecologie.gouv.fr/Identification-des-500-captages, 10136.html, create July $1^{\text {st }}, 2009$, consulted on December $15^{\text {th }}, 2009$.)

10 The Grenelle de l'environnement is an open multi-party debate in France that brings together representatives of national and local government and organisations (industry, labour, professional associations, non-governmental organisations) on an equal footing, with the goal of agreeing a uniform approach to a specific theme. The aim of the Grenelle Environment Round Table, instigated by the President of France, Nicolas Sarkozy, in the summer of 2007, is "to define the key points of public policy on ecological and sustainable development issues for the next five years." (http://en.wikipedia.org/wiki/Grenelle_Environnement, consulted on August $9^{\text {th }}, 2011$.) 11 These measures have replaced, but some of these contracts still apply until 2012. In view of the shortcomings of previous agri-environmental instruments, their re-deployment at territorial level is seen as more suitable to localised risks, and more conducive to the protection of areas of outstanding natural beauty (Natura 2000 and Grenelle water catchments). Actions to be implemented within a given territory are chosen by local project managers from a selection provided by the French State.

12 "In the water catchment areas [...] in application of the article R. 114-4 and in the twelve months following the publication of the action plan, the Préfet will make compulsory any measures in this program whose objectives will not, in his opinion, be attained at the conclusion of a twelve-month period." Decree $n^{\circ} 2007-882,14^{\text {th }}$ May, 2007 , concerning zones subjected to environmental requirements and modifying the rural code. 
held to account-for satisfying water quality objectives. In order to be environmentally efficient, the relevant territorial organisations need to decompartmentalise their internal and external policies. They need to create new, multi-partner, territorial methods of cooperation.

In this sense, the idea of water catchment areas would appear to be something of an innovation. It can be seen as a way of creating solidarity within territories, causing water to be treated as a truly shared resource. These catchment zones call for radical changes in farming methods (move to organic farming, or farming which uses a bare minimum of fertiliser and other soil additives).

In addition to encouraging dialogue between stakeholders, implementing the catchment device also defines clear sanitary and environmental goals for drinking water supplies. It means that official intervention can take place where voluntary or joint initiatives have been unsuccessful.

Taking all of this into account, it can be said that water catchments represent the device with the greatest potential for satisfying the objectives laid down in the WFD.

To what extent can the pertinence of drinking water issues, the government's objective driven-approach to water resources, and the introduction of a new tool bring about changes in drinking water quality governance?

\subsection{Moving towards new territorial drinking water governance regimes}

It is too early to say whether or not these new water protection measures have been effective ${ }^{13}$. Because of this, the analyses carried out in this paper were based on indicators of impending institutional change, using two territories, each with their own set of issues. The first territory studied, the Tarn-et-Garonne département, was classed as "farm-centred", meaning that intensive agriculture was prevalent ${ }^{14}$. In the case of Tarn-et-Garonne, the Chamber of Agriculture ${ }^{15}$ has always played an influential role in the implementation of agri-environmental measures. Territorial representatives of the French State and water agencies struggle to put in place any kind

13 Since the water catchment device is still in its infancy, it required specific methodological and analytical approaches. Much of the material used came from people recounting their own experiences, giving their opinions, and describing their own perspectives. In itinere analysis was used, meaning that the views and involvement of different stakeholders in connection with this new "catchment program" could be taken into account.

14 Tarn-et-Garonne is a rural département (91\% of municipalities) with 226,849 inhabitants (2006). Active farmland represents $60 \%$ of its surface area. In 2004, the department produced more apples and plums than anywhere else in France.

15 The Farmers'association is the body responsible for the agricultural interests of a French département. 
of significant agri-environmental project aimed at improving water quality. This corporate pressure from farmers looking to protect their own interests has gradually lead to difficulties in ensuring both the quantity and quality of drinking water ${ }^{16}$.

The second territory examined for this paper was the Charente département, which was classed as a "penalty risk", meaning that there was the possibility of an EU prosecution for non-compliance ${ }^{17}$. For this reason, the Charente département has been running an improvement initiative for water quality in catchment areas since $2000^{18}$, a system that provided a great deal of inspiration to those responsible for defining the Grenelle catchments, thirteen of which are located there.

While the analysis shows that there have been some innovations in recent years, these have not come from the agricultural profession, which still argues in favour of minor adjustments to farming practices, as opposed to drastic change. These innovations are rather the result of "new arrivals" in the drinking water quality debate.

Historically, agri-environmental devices have used means-based objectives. This means that farmers can ask for money to make changes to their officially-declared agricultural methods. This goes a long way towards explaining their failure to achieve any real environmental improvements. Throughout the '90s, environmental problems could no longer be ignored, leading to the entryism of the farming profession into agri-environmental politics (Brives, 1998). Efficiency requirements for drinking water quality tend to lead to strategic repositioning.

The "farm centred" territory is characterised by private stakeholders implementing an unprecedented public device with support from State representatives and the relevant water agency. In 2007, Qualisol, a

16 Département has only 44 water catchments for 195 municipalities. Three quarters of its land are classified as at risk from nitrates. Catchment sites regularly exceed pesticide parameters.

${ }^{7}$ The Charente is a rural département (for $92 \%$ of its municipalities), numbering 349,535 inhabitants in 2007. Agricultural zones (cattle, viticulture, cereals, polyculture) take up $62 \%$ of its surface area. This is further divided into $75 \%$ arable land, $11 \%$ permanent crops, and 14\% of land covered in grass (statistical data Agreste, 2007). Charente's 404 municipalities are supplied by only 99 catchment areas (93\% underwater sources). Since 2004 , health authorities have seen a steady increase in nitrate concentrations across $70 \%$ of these catchment areas.

18 The Re-sources program is a regional initiative aimed at increasing the quality of water in catchment areas. It is hoped that practices implemented at test sites will be rolled out to all catchments across the region. The key principles of the program are: collective agreement on the recognition of health and environmental issues, a multi-partner concerted approach, involvement of local authorities in co-ordinating and financing different types of action, combined funding from the State, water agencies and territorial officials, and sustainable changes to practices with an influence on the quality of water resources. 
farming co-operative and supplier of pesticides, became a pioneer in the implementation of a new set of Territorialised Agri-Environmental Measures (TAEMs) aimed at reducing the pesticide treatment frequency index on local farms. At its inception, it was estimated that 90 separate farmers agree to implement the new measures, representing some 4,000 hectares of land ${ }^{19}$. Qualisol's approach was to provide technical guidance to farmers in implementing methods that required less pesticide. The TAEM funding was then used to pay for these consultancy services, thus making up for reduced sales of chemical products. While this situation is not evidence of a change of paradigm, it does show a slight shift in the status quo. The handling of agri-environmental devices by a cooperative supplier of agricultural fertiliser de-stabilised the Farmers' Association, which is a good representation of the kind of intensive agriculture taking place on the territory. However, re-negotiating the role of the Farmers' Association by creating an arrangement with this co-operative did not lead to a greater representation of civil society. Drinking water syndicates, consumers and environmental associations do not really have any involvement with this type of regulation. More and more "conventional" market stakeholders (large scale food retailing, certifying organisations and marketing groups) want to get in on the agri-environmental act. These organisations are trying to tap into a "consumerist" movement which, paradoxically, comes from initial criticism of market mechanisms (Dubuisson-Quellier, 2009). It is clear that new result-driven agri-environmental initiatives are attributed less to conventional stakeholders, instead coming from organisations outside the standard intensive agricultural model: i.e. small-scale and organic farmers. Through the use of arguments based around sanitation and environmental quality, reduced overheads by less use of chemicals, and by changing their methods in anticipation of new regulations such as ECOPHYTO research programme 2018, these "small" stakeholders bring as much to the political debate as "green" organisations (Fouilleux, 2008).

Another case previously studied involves a territorial set-up, under the threat of EU drinking water quality disputes ${ }^{20}$. In this situation, local authorities are confronted with growing uncertainty relating to curative solutions. They are therefore forced to create incentives for "radical" change of their water production systems, in order to deal with agricultural pollution risks. This initiative is operated and co-financed by drinking water unions and territorial institutions (water agencies, regions and French départements) through public money, raised from both water bills and taxes.

19 This index represents the number of approved doses of a particular family of pesticides applied per hectare. The project is in operation in the Gimone watershed, which supplies water to the Beaumont de Lomagne catchment site (water provided to around 6,000 inhabitants).

${ }^{20}$ There is a firm collaboration between institutions at departmental level (State, General Councils, departmental water unions). A good example of this is the site we studied in Saint-Fraigne (Charente), where the president of the local drinking water syndicate is keen to be seen as forward-thinking. 
Looking at this information from an heuristic point of view, we can say that a "farm-based" set-up creates a situation of "market-driven territorial governance", while a "penalty risk" situation represents "user-centred territorial governance”.

At the same time, many other market and civil society participants are becoming involved in water quality. These new arrivals-farmers, associations and end users etc...-favour alternative solutions to those preferred by the dominant parties in agriculture (farm-to-table versus mass-market retailing). New participants also include large multinationals specialized in the delegation of drinking water public service.

If changes in drinking water governance actually are detected across these 500 designated water catchments, it remains to be seen whether or not the device will escape the problems posed by a "loss of sense" (Lorrain, 2004), and be rolled out successfully to other water territories. The analyses carried out in this paper have highlighted a climate of pessimism among many stakeholders. New water catchments seem to be caught in a vicious circle of palliative management. This negativity is, above all, a result of the strong messages contained in national water protection policy being diluted at local level. Water operators who will be called upon to implement new devices have criticised their use as a political tool. Among causes for complaint were press coverage, the arbitrary figure of 500 catchments, poorly thought-out objectives, and a lack of means. Local public bodies, responsible for implementation on a territorial level, must now answer to the State (which will be liable for any penalties) should they fail to achieve the specified targets. For this reason, many operators-particularly local authorities-are in favour of a "fresh approach" that will restore the credibility of the State in the eyes of the public.

Today, regulators are under increasing social pressure from water consumers. They demand transparency, as well as the right to their own input. More and more individual water users want access to information on water quality (nitrates, pesticides, residues of medicines, nanotechnology, and residues from water treatment). These new demands, which were initially centred on the quality and price of water for the end user, now reach much further. Consumers want to know about the quality of water at source (Grenelle de l'environnement, États généraux de l'eau in Toulouse since 2007). This greater degree of requirement has the potential to change the criteria for expectation of democracy and efficiency (Salles, 2006) in drinking water management.

In terms of mobilisation potential, the water catchment area device could well constitute a tool to restore the credibility, coherence and effectiveness of collective action as it applies to drinking water. Using the "bottom-up" effect, it has the potential to make the political world face up to its responsibilities. Where previously environmental issues were strategically appropriated by the farming community - thus neutralising or reducing the efficiency of statutory agri-environmental devices-this appropriation could be controlled. This 
kind of managed appropriation could become not simply an administrative tool, but a real tool in steering drinking water territories going forward.

\section{Conclusion}

In this paper, we have seen that environmental requirements are the most "permeable" elements in negotiation with the agricultural world. On the other hand, cleanliness is an important part of co-responsibility towards users, given the potential penalties for any shortcomings. In simple terms, managing sanitary risks through technical means is imperative for any authority.

Mechanical sanitary risk management is often accompanied by a management of the pitfalls facing elected representatives. Many authorities prefer to increase the price of water for the end user, rather than running the political risk of upsetting their dominant farming communities. It is clear, then, that palliative drinking water management is very much alive. This approach not only weakens water resources, but also contributes to creating delayed political and sanitary risks for those at all stages of the water "chain".

The new regulatory framework, along with the re-enforcement of water catchment perimeter protection, means that this position is no longer tenable. Elected representatives are responsible for inspections and penalties, sharing the legal responsibility for water cleanliness with the national health authorities. Local authorities therefore need to assume this responsibility, at the risk of rendering the State liable for penalties. Perversely, the policy of catchment protection actually shows a real convergence of neo-managerial government policy and the disengagement of local authorities. Figures are inflated through resource reassurance by catchment rationalisation. A short-term result-driven approach only serves to strengthen the palliative water management system that we have already seen.

At the same time, the responsibility for diffuse agricultural pollution and its causes are systematically sidelined into agri-environmental policy. Having analysed the implementation of agri-environmental devices, which supposedly integrate both agri- economic performances and results-driven objectives for water quality, it is clear that the agri-environmental model and environmental results policies are simply not compatible (Roussary et al., 2013).

While these contradictions are nothing new, they are pushed further into the public eye through a general preoccupation with impacts on public health, along with environmental result-driven policies. This is the main reason why drinking water protection devices such as source-quality management and the examination of agricultural practices did not appear until the late 2000s.

Despite being designed as an opportunity for fresh action, the "500 catchment" scheme is not without its critics.

It is designed to encourage local authorities to take part in ambitious, multi-partner agri-environmental action schemes. 
One striking result of this analysis is the identification of two different territorial governance regimes, both fairly innovative concerning the handling of agri-environmental devices. The first of these set-ups consists of the involvement of market stakeholders (specifically a farming co-operative in this case) who can see the future economic benefits of agri-environmental considerations.

The second configuration shows a voluntary policy that is open to changes in farming practices, under the overall control of local authorities. From a wider standpoint, we can see that alliances of this type tend to force the established agricultural organisations to work with these new players, on pain of losing legitimacy with financiers and farmers.

We can also see that technical and economic considerations, once considered key to changing farming practices, are giving way to a more sociological approach. However, it is clear that palliative management model is not without a hard core of proponents.

This is why the confirmation, and still uncertain environmental results, of these new regimes depend on water users receiving a clear explanation of very complex information relating to drinking water governance. It also requires collective mobilisation on the part of these consumers.

Following the example of other European countries (Germany), can these mobilisations lead to rebalance the power in the management of diffuse pollutions on drinking water territories?

There are several possibilities for further research. The future of the concept of territorial governance "by" users or "on behalf of" users is still fairly uncertain. The current extensive media coverage of chemical residues in distributed water gives rise to the question of whether increased action by private individuals and associations (successful legal action in the European Courts, water price renegotiation and changes in water control in several large municipalities) can make water quality concern to be focused on the causes of water pollution, rather than just dealing with already-polluted water.

Can France follow Germany's example in redressing the power balance of diffuse pollution management of drinking water territories?

Another topic deserving further investigation is environmental planning. Does the definition of 500 "target catchments" pave the way to the planning and rationalisation of water territories on a national scale?

Along the lines of early 20th-century town planning, these catchment basins would be subject to much more strictly controlled farming activities. Of course, the risk of attention being focused on these "special" catchments is that diffuse pollution in other areas will be neglected. However, in the current climate of European disputes, lack of scope for any more rationalisation in many French départements, and the willingness of many territorial institutions to significantly exceed laid-down objectives, it would seem that there is a potential for improvements to be made in territorial public action on drinking water. 
State services, water agencies and local authorities require further expertise to enable them to install a sense of solidarity between drinking water suppliers, farmers and consumers.

One additional line of research is the role that sociology has to play. Sociologists are capable of "enlightening society" (Boltanski, 2009) - through objectification of drinking water issues - on the contradictions and possible consequences of political actions. They can help to understand the effect of individual practices and the dynamics of collective action. Where sociology constitutes a form of critical contributory mediation (Uhalde, 2008) it could contribute in itinere to significant changes in territorial governance of drinking water quality (Roussary and Salles, 2010).

\section{Acknowledgment}

This communication is based on part of the main results of the doctoral thesis: Towards a reorganisation of the drinkable water governance. Of the sanitary conformity with the requirement of environmental quality, presented on May 25th, 2010 at the University of Toulouse 2 Le Mirail in France.

Thanks to James Emery, for his assistance with English proofreading.

\section{References}

Barbier R. (2011) La sécurisation de l'approvisionnement en eau potable : un tour d'horizon des enjeux et des leviers d'action, in : Des tuyaux et des bommes : Les réseaux d'eau en France, Bouleau G. and Guérin-Schneider L. (eds), Paris, Quae, 123-134.

Barbier R., Caillaud K., Canneva G., Ghiotti S., Large A., Renaud E., Roussary A., Salles D. and Werey C. (2011) Le changement d'échelle dans l'action publique environnementale. Analyse comparée de régimes de gouvernance départementale de l'eau destinée à la consommation bumaine, The international conference Territory and Environment: from representations to action, December 8-9, 2011, Tours, France.

Barraqué B. (ed), Bosc C., Doussan I. and Viavattene C. (2007) Eau des Villes, Eau des Champs. Pour une évaluation adaptée à la démarche du développement durable, Rapport final de recherche, Programme D2RT du ministère de l'Écologie, 186 p.

Becerra S., Roussary A. (2008) Gérer la vulnérabilité de l'eau potable : une action publique désengagée ?, Natures, Sciences et Sociétés, 16, 220-231.

Becerra S., Peltier A. (eds) (2009) Risques et environnement : recherches interdisciplinaires sur la vulnérabilité des sociétés, Paris, L'Harmattan. 
Bezes P. (2008) Le tournant néomanagérial de l'administration française, in : Politiques publiques. 1, La France dans la gouvernance européenne, Borraz O. and Guiraudon V. (eds), Paris, Presses de Sciences Po, 215-254.

Boltanski L. (2009) De la critique. Précis de sociologie de l'émancipation, Paris, Gallimard, 294 p.

Borraz O., Gilbert C. and Joly P.-B. (2005) Risques, crises et incertitudes : pour une analyse critique, Grenoble, MSH Alpes, $257 \mathrm{p}$.

Bourblanc M. (2007) Les politiques de reconquête de la qualité de l'eau face aux pollutions agricoles : Changement et stabilité dans les arrangements institutionnels en Côtes-d'Armor (France) et dans le Noord-Brabant (Pays-Bas), Thèse de doctorat en science politique et en science de gestion, Institut d'Études Politiques de Paris et la Radboud Universiteit Nijmegen, Pays-Bas.

Brives H. (1998) L'environnement, nouveau pré-carré des Chambres d'Agriculture, Ruralia, 2, 73-83.

Busca D. (2010) L'action publique agri-environnementale. La mise en ceuvre négociée des dispositifs, Paris, L'Harmattan, 329 p.

Canneva G., Pezon C. (2008) Des communes aux communautés, la révolution invisible des services d'eau en France, Flux, 74(4), 56-67.

Costa O., Jabko N., Lequesne C. and Magnette P. (2001) La diffusion des mécanismes de contrôle dans l'Union Européenne : Vers une nouvelle forme de démocratie ?, Revue française de science politique, 51(6), 859-866.

Daniel F.-J. and Perraud D. (2009) The multifunctionality of agriculture and contractual policies. A comparative analysis of France and Netherlands, Journal of Environmental Management, 90 (Supplement 2), 132-138.

Dubuisson-Quellier S. (2009) La consommation engagée, Paris, Presses de Sciences Po, $143 \mathrm{p}$.

Duran P., Thoenig J-C. (1996) L'État et la gestion publique territoriale, Revue Française de Science Politique, 46(4), 580-623.

Faucher-King F., Le Galès P. (2007) Tony Blair, 1997-2007. Le bilan des réformes, Paris, Presses de Sciences Po, 150 p.

Fouilleux E. (2008) Les politiques agricoles et alimentaires, in : Politiques publiques. 1, La France dans la gouvernance européenne, Borraz O. and Guiraudon V. (eds), Paris, Presses de Sciences Po, 113-146.

Grandgirard A., Barbier R. and Tsanga Tabi M. (2009) Le Département, un acteur clef de la politique de l'eau, Économie rurale, 309(1), 22-33.

Grémion P. (1976) Le pouvoir périphérique. Bureaucrates et notables dans le système politique français, Paris, Le Seuil, 472 p. 
Hache E. (2007) La responsabilité, une technique de gouvernementalité néolibérale?, Raisons politiques, 28(4), 49-65.

Hirschman A.O. (1970) Exit, voice and loyalty: Responses to decline in firms, organizations and states, Cambridge, Harvard University Press, 162 p.

IFEN (Institut Français de l'Environnement) (2007), Les services publics de l'eau en 2004. Volet eau potable, Les dossiers, 7, octobre, 34 p.

Lascoumes P. (1990) Normes juridiques et mise en œuvre des politiques publiques, L'Année sociologique, 40, 43-71.

Lascoumes P., Le Galès P. (2004) Gouverner par les instruments, Paris, Presses de Sciences Po, $370 \mathrm{p}$.

Lorrain D. (2004) Les pilotes invisibles de l'action publique. Le désarroi du politique?, in : Gouverner par les instruments, Lascoumes P. and Le Galès P. (eds), Paris, Presses de Sciences Po, 163-197.

Narcy J.-B. (2004) Pour une gestion spatiale de l'eau. Comment sortir du tuyau?, Bruxelles, P.I.E.-Peter Lang collection, Ecoplis n4, 342 p.

Notte O., Salles D. (2011) La prise à témoin du public dans la politique de l'eau. La consultation directive-cadre européenne sur l'eau en AdourGaronne, Politique européenne, 33(1), 37-62.

Ministry of Health (2008) L'eau potable en France 2005-2006. Études Eau et Santé, Ministère de la Santé, de la Jeunesse, des Sports et de la Vie associative, Paris, Septembre, 66 p.

Ministry of Health (2010) Bilan de la qualité de l'eau au robinet $d u$ consommateur vis-à-vis des pesticides en 2008, Ministère de la santé et des Sports, http://www.sante.gouv.fr/IMG/pdf/Bilan_de_la_ qualite_de_1_eau_au_robinet_du_consommateur_2010.pdf, site consulté le 18 février 2014, 11 p.

Pierson P. (2000) Increasing returns, Path dependence and the study of politics, American Political Science Review, 94(2), 251-267.

Roussary A. and Salles D. (2010) Pollutions agricoles et qualité de l'eau potable : vers une interdépendance des dispositifs de gestion, Colloque international Eau, Lien social et dynamique locale, Hammamet, Tunisia, April 15-17, 2010.

Roussary A., Busca D., Salles D., Dumont A. and Carpy-Goulard F. (2013) Pratiques phytosanitaires en agriculture et environnement : des tensions irréductibles ?, Économie rurale, 333, 69-83.

Roussary A. (2013) De l'eau potable au robinet? Santé, environnement et action publique, Paris, L'Harmattan, $418 \mathrm{p}$.

Salles D. (2006) Les défis de l'environnement. Démocratie et efficacité, Paris, Syllepse, $250 \mathrm{p}$. 
Salles D. (ed), Barraqué B., Busca D. and Garin P. (2006) L'Eau des Villes et L'Eau des Champs. Négociation territoriale et Génie de l'Environnement (EVEC), Rapport final de recherche, Programmes CNRS - PIDUD (Programme Interdisciplinaire Développement Urbain Durable) et D2RT (Politiques territoriales et Développement Durable) des deux ministères de l'écologie et de l'équipement, 271 p.

Salles D. (2009) Environnement : la gouvernance par la responsabilité ? VertigO - La revue électronique en sciences de l'environnement, Hors série 6, URL : http://vertigo.revues.org/9179.

Uhalde M. (2008) L'instrumentalisation de la sociologie en situation d'intervention ; analyse critique d'une notion ordinaire, Sociologies Pratiques, 16(1), 95-113. 